\title{
CoNF-970654--1
}

\section{THE DEVELOPMENT OF A SPREADSHEET-ATDED-ENGINEERING DESIGN TOOL FOR PARACHUTES}

\author{
Donald E. Wayet and Larry D. Whinery" \\ Sandia National Laboratory§ \\ Albuquerque, New Mexico
}

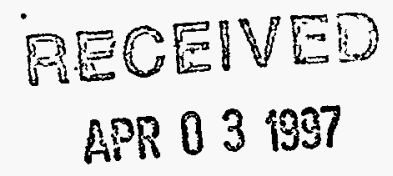

\begin{abstract}
$\underline{\text { Abstract }}$
A spreadsheet-aided engineering design tool has been developed to assist in the parachute design process. The new tool was developed during FY96 and utilized in the design of the flight termination parachute system for a $1900 \mathrm{lb}$. payload [ref. 1]. Many modifications were made during the initial utilization of this tool. Work on the tool continues as we attempt to create an application tool for the parachute engineer.
\end{abstract}

\section{Introduction}

For many years Sandia has developed computer codes to model explicit portions of the parachute deployment and inflation process, and to evaluate the loads in the parachute structure. In order to use these codes the parachute designer first has to follow a process which directs him/her in the selection of a parachute, estimation of parachute loads, determination of the need for reefing, and an estimation of the parachute drag area versus time curve to be used in the force-time-trajectory computer code. Much of this process has been presented by the first author at several University of Minnesota parachute technology short courses [ref. 2]. Following this initial process each of the individual, detailed components of the parachute must be designed. This involves the determination of ribbon, ring, and/or solid gore section widths; spaces between the individual parachute members, if

† Senior Member of Technical Staff, Production Program Management Department, Associate Fellow of AIAA.

* Team Supervisor, Parachute Laboratory, Unsteady and Reactive Fluid Mechanics Department.

$\S$ Sandia is a multiprogram laboratory operated by Sandia Corporation, a Lockheed Martin Company, for the United States Department of Energy under contract DE-AC0494AL85000.

This paper is declared a work of the U.S. Government and is not subject to copyright protection in the United States. required; number of gores, etc. Many time multiple iterations of the design are performed during this initial design process before the final parachute design is determined.

Following this process the materials for each of these components must be selected based on the calculated strength. After this process the one answer that the parachute designer is required to provide to the customer is the weight of the parachute and a confirmation that the parachute will fit within the volume provided in the system.

We have desired for years to make this process easier for the parachute designer and allow for timely iterations during the design process. In addition, we would like to be able to integrate the design process with the line deployment, force-timetrajectory, and structural codes that are at our disposal. This spreadsheet-aided engineering design tool is the initial attempt at fulfilling this desire.

\section{Spreadsheet-Aided-Engineering}

As spreadsheets have become more powerful in recent years they have progressed from simple business tools to simple data analysis tools to valuable engineering tools. They now have the capability to create graphical user interfaces, to command other languages such as FORTRAN and $C$, and to control an integrated object oriented programming environment called VBA. These capabilities allow the parachute engineer to create and build applications that perform many of the repetitive design and analysis tasks associated with the design and development of a parachute system.

The Sandia parachute design spreadsheet tool has been created on the personal computer using Microsoft Excel. The command modules utilize the visual basic application (VBA) language embedded within the Excel software package. This language can be used to perform the more complicated calculations and also can be used to control the spreadsheet environment and create linkages to the 


\section{DISCLAIMER}

Portions of this document may be illegible in electronic image products. Images are produced from the best available original document. 
FORTRAN codes that have been used for years in parachute design.

One of the perceived benefits of using the spreadsheet as a platform for the development of this design tool is the availability of the inputs and outputs on the computer screen. Design iterations are nearly instantaneous and can be viewed as an integrated package. Methods for manipulating the Excel software package and using VBA are being taught by Professor Tom R. Mincer, Ph.D through the University Consortium for Continuing

Education. Dr. Mincer has extensive experience with the use of spreadsheets for large scale system engineering.

\section{Tool Components}

\section{Introduction}

The PC based design tool that we have been developing consists of several interactive Microsoft Excel spreadsheets that guide the design engineer through the design process, calculate initial values, and then help to create the tables that are required as input to the FORTRAN analysis computer codes. Development work is in progress to create the linkages that will call the FORTRAN codes using the Excel input tables and then return the code output for graphical display and use in the following steps in the design process.

Figure 1 illustrates the high-level flow of information through the spreadsheets during the design process: There remains a large amount of work to create the "expert" systems and automation that will complete the vision anticipated for this design program.

The following sections describe and illustrate the spreadsheet program in its current status. Each of the pages (or sheets) in the program and the linkages are described. Future development of the program are also forecast where appropriate.

\section{Initial Design Calculations - Sheet 1}

The first sheet of the spreadsheet-aided design tool provides a location to input the parachute requirements of the system and then to calculate the preliminary parachute design. Due to the great variations in parachute design requirements there is

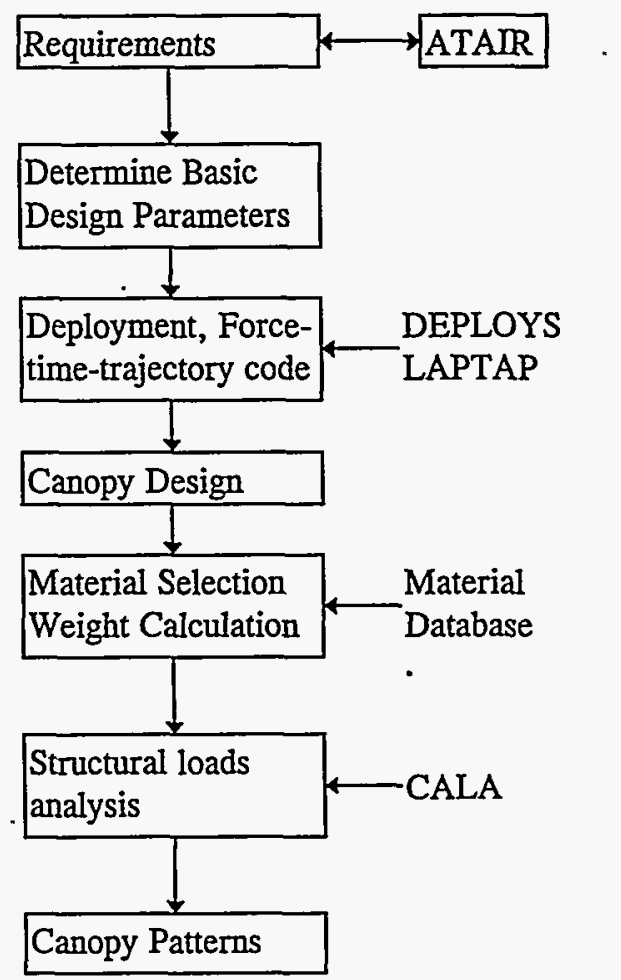

Figure 1 - Design Tool Overview

some need for the parachute designer to make choices during this early design process.

This page (see figure 2)v allows the design engineer to select the parachute drag coefficient and suggests a parachute diameter based on required impact velocity. However, if the impact velocity is not the main requirement the tool also allows for the parachute diameter to be based on maximum deceleration level. The parachute designer then selects the diameter desired for the system.

Based on the input diameter, obrag coefficient, and maximum load requirement the tool determines if reefing is required and suggests a suitable reefed diameter to ensure that the maximum load is not exceeded. These calculations are based on the Wt/CdS method described by Knack [ref. 3] and the reefing line length versus drag area ratio curve [ref. 3]. Both of the empirical curves used for this calculation have been converted into equations and incorporated into the program.

Following the load calculations the time for inflation of the parachute is calculated. The factor and equation used in these calculations must be selected by the design engineer. For a parachute design in which reefing is required the program 


\section{SANDIA PARACHUTE DESIGN TOOL}

\section{Enter Requirement Parameters}

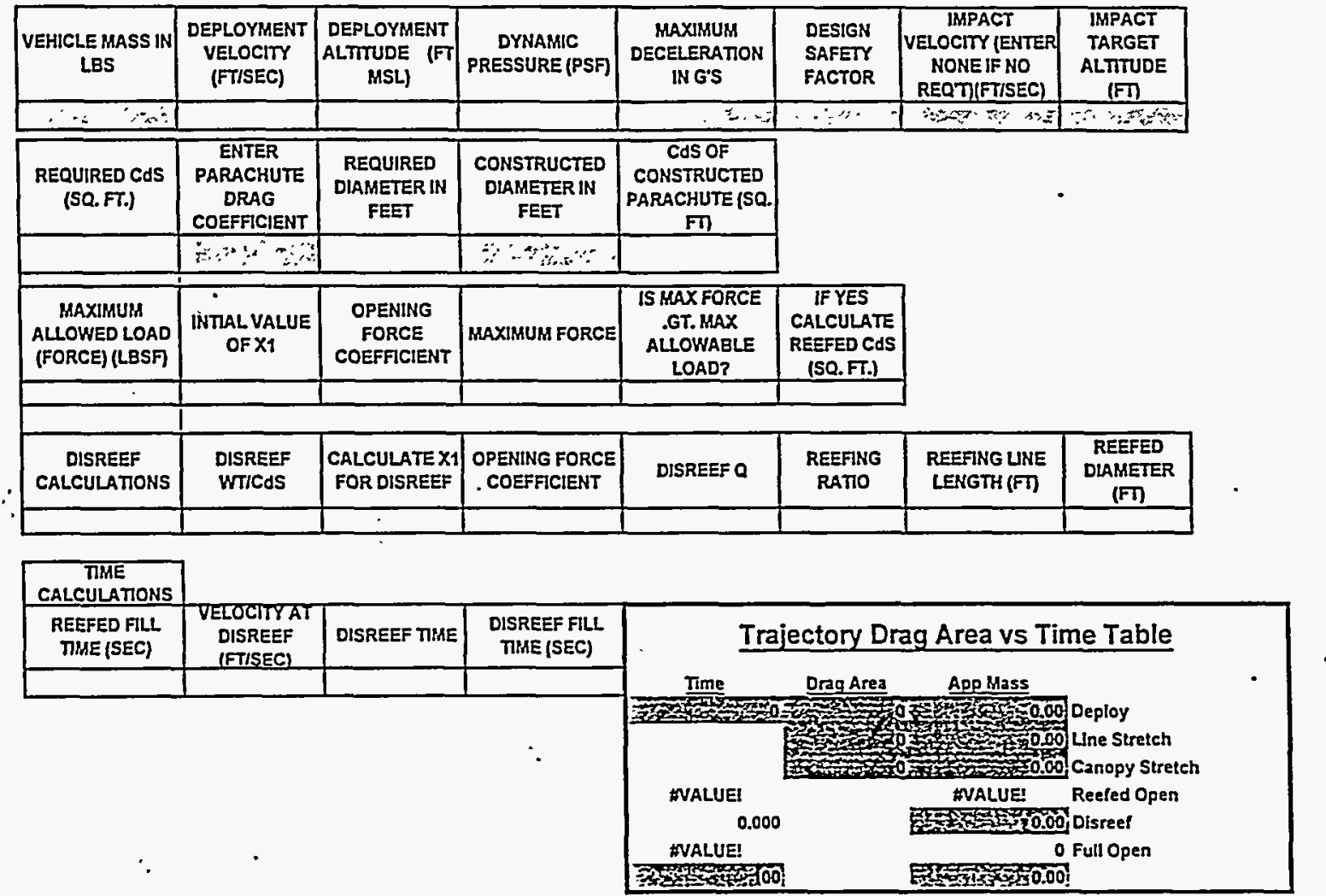

Figure 2 - Initial Design Calculations -- Sheet 1

suggests the required dynamic pressure for disreefing to ensure that the maximum load is not exceeded. The portion of the drag area versus time table required for the reefed parachute is determined and printed on the spreadsheet. At the present time, the design engineer is required to run the trajectory program using the calculated time versus drag area input for the reefed parachute in order to find the time and velocity for disreefing of the parachute.

Following this step a reefing line cutter delay time is selected, the velocity at disreef is input, and the full-open inflation time is calculated. This completes the time versus drag area table. Again, the design engineer must separately run the trajectory code to obtain the force versus time and trajectory history of the parachute.

Future iterations of this sheet in the design tool will create the VBA linkages required to directly call the FORTRAN force-time-trajectory code. The output will then be inserted into the spreadsheet environment and displayed in tabular and graphical form.. If reefing is required the code will first be used to determine the correct time for disreefing the parachute and then, a second time, to model the complete parachute design.

It is obvious from this description of sheet 1 that the design engineer must consider several alternatives and make many choices before he can determine if a parachute can be designed that will meet the requirements. Future development of this initial design process sheet may include "expert" system modules that will aid the design engineer through these alternatives and suggest standard parameters for the choices required.

\section{ATAIR - Sheet 2}

The second sheet in the program is named ATAIR (Atmosphere and AIRspeed) and is illustrated in figure 3 . This sheet interacts with sheet 1 and is used to evaluate the system requirements by converting inputs of altitude and 


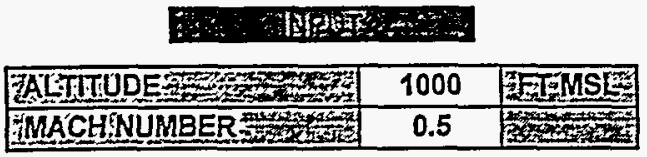

\begin{tabular}{|c|c|c|}
\hline 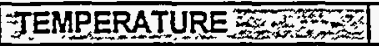 & 515.12 & MEGR \\
\hline 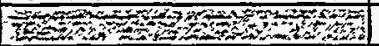 & 55.43 & FDEFF \\
\hline PRESSURE & 2040.86 & 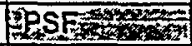 \\
\hline DENSITY & 0.002308 & SSEUGSIEI2 \\
\hline SPEED OF SOUND & 1112.62 & FEISEC \\
\hline DYNAMIC PRESSURE & 357.15 & PSSEX \\
\hline MACH NUMBER ZEREA & 0.50 & 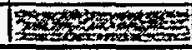 \\
\hline CALIBRATED AIRSPEED & 325.13 & BNOTS 34 \\
\hline 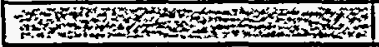 & 548.76 & TEISEC \\
\hline EQUIVALENTAIRSPEED & 324.80 & FNOTS \\
\hline 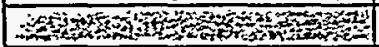 & 548.19 & SETLSEO \\
\hline TRUE AIRSPEED & 329.60 & KNOIS, \\
\hline 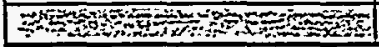 & 556.31 & TIISEC \\
\hline
\end{tabular}

Figure 3 - ATAIR

velocity to outputs of calibrated, equivalent, and true velocity in units of knots and feet per second. In addition, the temperature, pressure, density, and speed of sound of the atmosphere at the input altitude are calculated and the dynamic pressure is determined. All calculations are performed using standard US atmosphere.

This spreadsheet was created through the conversion of a simple FORTRAN code which performed the same function. The advantage of the spreadsheet version is that the alternatives are more easily considered and iterative solutions are much easier to manually manipulate. However, the disadvantage of this program is that only the standard atmosphere is used. There are various FORTRAN and $\mathrm{C}$ based codes that calculate conditions for many non-standard atmospheres (i.e. winter, summer, northern latitudes, etc.). The creation of VBA language linkages to these codes would create a flexibility for specific parachute design applications.

\section{Canopy Design - Sheet 3}

The third sheet of the design tool begins the physical design of the parachute canopy. The parachute diameter is passed from sheet $I$ and the design engineer specifies the parachute cone angle and number of gores. He then interactively determines the vent diameter for the parachute using a help that calculates and compares the input diameter to the recommended $10 \%$ vent diameter. Next, the engineer specifies the appropriate ribbon, ring, and/or solid section widths and spaces (if . required). This sheet in based on the method of geometric construction of the parachute as described by the first author in a computer code for conical ribbon design [ref. 4]. The output of the program includes local and overall geometric porosity of the parachute, vent percentage, radial length, total drag area, and nominal diameter.

Again, the spreadsheet platform allows the parachute design engineer to interactively design the parachute and view the results immediately on screen. Many alternate designs can be evaluated based on the desired criteria. For example, for a ribbon parachute alternate ribbon quantities, width, and spacing can be evaluated versus overall and local porosity. Figure 4 illustrates the "look and feel ${ }^{n}$ of this sheet through the example of a simple ribbon parachute design.

\section{Material Selection/Canopy Weight - Sheet 4}

The fourth sheet in the design tool aids the parachute designer in the selection of materials for the parachute components (i.e. radial, suspension lines, ribbon, rings, skirt band, vent band, etc.). Using the maximum load information from sheet 1 


\begin{tabular}{|c|c|c|c|c|c|c|c|c|c|c|}
\hline $\begin{array}{c}\text { CONSTRUCTE } \\
\text { D DIAMETER } \\
\text { IN ERET }\end{array}$ & $\begin{array}{c}\text { CONE } \\
\text { ANGLE } \\
\text { IN } \\
\text { DEGREES }\end{array}$ & $\begin{array}{l}\text { VENT } \\
\text { DIAMETER } \\
\text { (IN) }\end{array}$ & $\begin{array}{l}\text { VENT IINE } \\
\text { IINGIA } \\
\text { (IN) }\end{array}$ & $\begin{array}{l}\text { NUMBER } \\
\text { OF } \\
\text { GORES }\end{array}$ & $\begin{array}{l}\text { FIDTH OE } \\
\text { RADIAIS } \\
\text { (IN) }\end{array}$ & $\begin{array}{l}\text { FIDTE OE } \\
\text { NIINI } \\
\text { RADIAIS } \\
\text { (IN) }\end{array}$ & $\begin{array}{l}\text { SUSP. } \\
\text { IDNE } \\
\text { IENTGIE } \\
\text { (ET) }\end{array}$ & $\begin{array}{l}\text { AREA OE } \\
\text { THE } \\
\text { ERUSTRUA } \\
\text { (SQET) }\end{array}$ & $\begin{array}{l}\text { TOLAI } \\
\text { AREA } \\
\text { (INCLUDE } \\
\text { VENT) } \\
\text { SOET } \\
\end{array}$ & $\begin{array}{c}\text { TOTAL } \\
\text { FOROSITY }\end{array}$ \\
\hline$-x \cdot 3 \cdot x=1$ & $20 \times 3$ & $\frac{6}{2 x^{2}} 9.18 ;: i=$ & 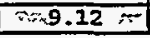 & $-16 \quad \cdots$ & $=1$ & $\therefore 0.5=$ & $2: 16 \div 3$ & 53.00 & 53.46 & 19.948 \\
\hline $\begin{array}{c}\text { CONSTRUCTE } \\
\text { D DIAMETER } \\
\text { IN INCAES }\end{array}$ & $\begin{array}{c}\text { CONE } \\
\text { ANGLE } \\
\text { IN } \\
\text { RADIANS }\end{array}$ & 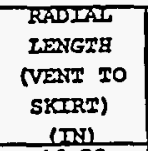 & $\begin{array}{c}\text { VENTI } \\
\text { DERCENT OE } \\
\text { CONST. } \\
\text { DIA. }\end{array}$ & 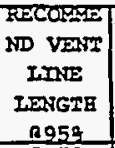 & $\begin{array}{l}\text { VENT IINE } \\
\text { BERCENT } \\
\text { OE VENT } \\
\text { DIA. }\end{array}$ & $\begin{array}{l}\text { VaNT } \\
\text { RADIUS } \\
\text { (IN) }\end{array}$ & $\begin{array}{l}\text { APEX TO } \\
\text { VENT (IN) }\end{array}$ & $\begin{array}{c}\text { AREA OE } \\
\text { VENTI } \\
\text { (SQIN) }\end{array}$ & $\begin{array}{l}\text { VENT } \\
\text { POROS. }\end{array}$ & $\begin{array}{l}\text { AREA OE } \\
\text { PARACAUTE } \\
\text { SKIRT } \\
\text { ORENING } \\
\text { (SOET) }\end{array}$ \\
\hline 96.00 & 0.34907 & 46.20 & 9.568 & 8.72 & 99.408 & 4.59 & 4.88 & 66.12 & 19.798 & 50.27 \\
\hline $\begin{array}{l}\text { NUMBER OF } \\
\text { RIEEONS }\end{array}$ & $\begin{array}{l}\text { ATMBER } \\
\text { OE } \\
\text { SPACES }\end{array}$ & $\begin{array}{c}\text { VENTI AREA } \\
\text { COVERED } \\
\text { (SQIN) }\end{array}$ & $\begin{array}{c}\text { VENT AREA } \\
\text { OREN } \\
\text { (SQIN) }\end{array}$ & $\begin{array}{l}\text { RADIUS } \\
\text { OE OREA } \\
\text { VEATI } \\
\text { (INI) }\end{array}$ & $\begin{array}{l}\text { RADIUS OF } \\
\text { CLOSED } \\
\text { VIIII (IN) }\end{array}$ & $\begin{array}{l}\text { TOTAI } \\
\text { GORE } \\
\text { AREA } \\
\text { (SQIA) }\end{array}$ & $\begin{array}{c}\text { GORE } \\
\text { POROSITY }\end{array}$ & $\begin{array}{c}\text { TOTAI. } \\
\text { ORSA AREA } \\
\text { (SQ ET) }\end{array}$ & $\begin{array}{l}\text { - TORAL } \\
\text { DRAG } \\
\text { AREA } \\
\text { (SQET) }\end{array}$ & $\begin{array}{l}\text { NOMTIAL } \\
\text { DIAMETER } \\
\text { (EEET) }\end{array}$ \\
\hline 18 & $\overline{17}$ & 53.03 & 13.09 & 2.04 & 2.55 & 477.04 & 19.98 & 10.66 & 42.80 & 8.25 \\
\hline
\end{tabular}

\begin{tabular}{|c|c|c|c|c|c|c|c|c|c|c|}
\hline 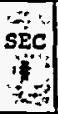 & 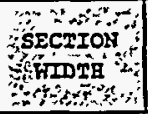 & 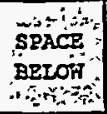 & $\begin{array}{l}\text { GORE FIDTA } \\
\text { (IOP) }\end{array}$ & $\begin{array}{c}\text { GORE FIDTE } \\
\text { (BOTIOA) }\end{array}$ & $\begin{array}{l}\text { WWMBRR } \\
\text { OE MTII } \\
\text { RADIAIS }\end{array}$ & $\begin{array}{c}\text { RADIAL } \\
\text { TENGAB } \\
\text { REAADIANG }\end{array}$ & $\begin{array}{l}\text { IOCAT } \\
\text { GORE } \\
\text { AREA }\end{array}$ & $\begin{array}{c}\text { IOCAI } \\
\text { SLOT AREA }\end{array}$ & $\begin{array}{l}\text { IOCAI } \\
\text { EOROSIIYY }\end{array}$ & $\begin{array}{l}\text { AVERAGE } \\
\text { EOROSITY }\end{array}$ \\
\hline 1 & 2.00 & 0.60 & 1.80 & 2.54 & & 43.60 & 5.93 & 0.99 & 16.698 & 27.978 \\
\hline 2 & 2.00 & 0.60 & 2.76 & 3.50 & & 41.00 & 8.43 & 1.57 & 18.588 & 28.258 \\
\hline 3 & 2.00 & 0.60 & 3.72 & 4.46 & & 38.40 & 10.92 & 2.14 & 19.618 & 18.758 \\
\hline 4 & 2.00 & 0.60 & 4.68 & 5.42 & & 35.80 & 13.41 & 2.72 & 20.258 & 19.228 \\
\hline 5 & 2.00 & 0.60 & 5.64 & 6.38 & & 33.20 & 25.91 & 3.29 & 20.708 & 19.628 \\
\hline 6 & $2.00^{\circ}$ & 0.60 & 6.60 & 7.34 & & 30.60 & 28.40 & 3.87 & 21.028 & 19.968 \\
\hline 7 & 2.00 & 0.60 & 7.56 & 8.30 & & 28.00 & 20.90 & 4.44 & $21.27 \%$ & 20.248 \\
\hline 8 & 2.00 & 0.60 & 8.52 & 9.26 & & 25.40 & 23.39 & 5.02 & 21.468 & 20.478 \\
\hline 9 & 2.00 & 0.60 & 9.48 & 10.22 & & 22.80 & 25.89 & 5.60 & 21.618 & 20.678 \\
\hline 20 & 2.00 & 0.60 & 10.44 & 11.17 & & 20.20 & 28.38 & 6.17 & 21.748 & 20.848 \\
\hline 11 & 2.00 & 0.60 & 11.40 & 12.13 & $\therefore$ & 17.60 & 30.88 & 6.75 & $21.85 \mathrm{z}$ & 21.008 \\
\hline 22 & 2.00 & 0.60 & 12.36 & 13.09 & & 15.00 & 33.37 & 7.32 & 21.948 & 21.138 \\
\hline 13 & 2.00 & 0.60 & 13.31 & 14.05 & & 12.40 & 35.87 & 7.90 & 22.025 & 21.248 \\
\hline 14 & 2.00 & 0.60 & 14.27 & 15.01 & & 9.80 & 38.36 & 8.47 & 22.098 & 21.358 \\
\hline 15 & 2.00 & 0.60 & 15.23 & 15.97 & & 7.20 & 40.85 & 9.05 & 22.158 & 21.448 \\
\hline 16 & 2.00 & 0.60 & 16.19 & 16.93 & & 4.60 & 43.35 & 9.63 & 22.208 & 21.528 \\
\hline 17 & 2.00 & 0.60 & 17.15 & 17.89 & & 2.00 & 45.84 & 10.20 & 22.253 & 21.608 \\
\hline 18 & 2.00 & & 18.11 & 18.85 & . & 0.00 & 36.96 & 0.00 & 0.008 & 19.948 \\
\hline
\end{tabular}

Figure 4 - Canopy Design -- Sheet 3

and the geometry from sheet 3 the program uses standard equations to suggest the required material strengths required for each component. The design engineer then uses this information to select a material from the material database sheet and inputs the properties. Following the selection of the material and its properties the program utilizes the geometric parameters from the third sheet to calculate the amount of material required and estimates the weight of the component. The weights of each component are then summed.

The design engineer is allowed to include the weight of reefing rings, reefing line cutters, knives, and the deployment bag to the summation of the material components in order to estimate the total weight of a packed parachute.
The material database sheet is an auxiliary page to this sheet and contains all of the nylon and Kevlar webs, tapes, and cloth material specifications to aid the designer in choosing materials. The future development of the material selection sheet includes the creation of an "expert" system for material selection that will automatically suggest the correct material for each parachute component and, upon final selection, automatically input the properties. CALA - Future Development

The detailed geometric and material design of the parachute contained on sheets 3 and 4 contain all of the geometric and material input data required by the CALA code [ref. 5] to perform a steady state structural analysis. However, another spreadsheet will be required to aid the design engineer create the pressure distribution input required by CALA. This information will be placed into an input vector that 
will be used by the VBA language as input to the CALA structural code. Output of the code will be brought back into Excel and graphically displayed to illustrate the structural margin of the parachute.

\section{Pattern Sheets}

Following the design and analysis of the parachute the next task is to create patterns for parachute fabrication. Several spreadsheet pages follow the main design sheets which are used to determine the specifications for the ribbons, rings, and solid patterns. These sheets use the data from sheet 3 to calculate the $x-y$ coordinates for each ribbon, ring, or solid pattern.

Each of the sheets require that the design engineer provide inputs such as seam widths, material width, or seam overlap length, dependent on the component pattern being calculated. An example of the ring pattern sheet is shown in figure 5.

\begin{tabular}{|c|c|c|c|c|c|c|c|c|c|}
\hline RING\# & & $\begin{array}{c}\text { TOR SEAM } \\
\text { WIDTE }\end{array}$ & $\begin{array}{c}\text { BOTTOM } \\
\text { SEAM } \\
\text { WIDTH } \\
\end{array}$ & $\begin{array}{c}\text { GORE } \\
\text { WIDTR } \\
\text { TOR } \\
\end{array}$ & $\begin{array}{c}\text { GORE } \\
\text { FIDTE } \\
\text { BOTTOM } \\
\end{array}$ & $\begin{array}{l}\text { FIDTE OF } \\
\text { RADIAL }\end{array}$ & $\begin{array}{c}\text { RING } \\
\text { ESIGAT }\end{array}$ & $\begin{array}{c}\text { NUMBER } \\
\text { OE } \\
\text { SECTIONS }\end{array}$ & $\begin{array}{l}\text { EORE } \\
\text { ANGLE } \\
\text { (RAD) }\end{array}$ \\
\hline 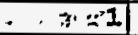 & & $\because 00.50$ & $y=-50.50$ & 1.80 & 3.65 & 1.00 & 5.00 & 17 & 0.369 \\
\hline & & & & & & & & & \\
\hline - & $\mathrm{x}$ & $\Psi$ & & $\begin{array}{l}\text { PANEL } \\
\text { CENTER } \\
\text { LINE }\end{array}$ & & & $\begin{array}{l}\text { RADIAI } \\
\text { CENTIER } \\
\text { IINES }\end{array}$ & & \\
\hline & 0.0001 & 0.000 & & $\mathrm{x}$ & $Y$ & & $\mathrm{x}$ & $\bar{Y}$ & \\
\hline & 2.010 & 0.000 & & 0.000 & 0.000 & & 2.0101 & 0.000 & \\
\hline & . 3.536 & 0.000 & & 0.000 & 7.000 & & 0.714 & 7.000 & \\
\hline & 3.349 & 1.000 & & & & 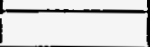 & & & \\
\hline & 2.427 & 6.000 & & TOP IINE & & i & -0.714 & 7.000 & \\
\hline & 2.240 & 7.000 & & $\begin{array}{ll} & \\
\end{array}$ & $\bar{Y}$ & & -2.010 & 0.000 & \\
\hline & $0.714:$ & 7.000 & & 2.427 & 6.00 & & & & \\
\hline & $0.000 !$ & 7.000 & & -2.427 & 6.00 & & & & \\
\hline & -0.714 & 7.000 & & & & & & & \\
\hline & -2.240 & 7.000 & & BOTTOM LI & & & & & \\
\hline & -2.427 & 6.000 & & $x$ & $Y$ & & & & \\
\hline & -3.349 & 1.000 & & 3.349 & 1.00 & & & & \\
\hline . & -3.536 & 0.000 & & -3.349 & 1.00 & & & & \\
\hline & -2.010 & 0.000 & & & & & & & \\
\hline & 0.000 & 0.000 & & & & & & & \\
\hline
\end{tabular}

Figure 5 - Ringslot Pattern Example

\section{Miscellaneous Sheets}

Several additional sheets are also currently included in the tool. Some of these sheets have not been fully integrated into the program and stand alone. For example, one sheet contains the equations used to determine pocket band dimensions. A second sheet finds the density of the packed parachute given the allowable dimensions in the vehicle. A third sheet allows the designer to specify canopy tie, retainer, and lacing knife loops. Finally, another sheet contains a location to specify and record sewing threads, patterns, and number of rows to be used to attach different components.

\section{$\underline{\text { Recommendations }}$}

The complexity and variety of parachute design makes the task of developing a "universal" parachute design tool difficult. We have taken the path of creating a design tool that is applicable to the standard conical geometry parachute problem and used the one-body analysis code for the initial design tool development. We have followed this path in order to show actual results and demonstrate the value of using the spreadsheet as a platform for parachute design. We recommend that complexity (i.e. two-body trajectory, other types of parachute design and analysis, etc.) be added incrementally and in a manner consistent with the needs of the organization and/or engineer. 


\section{Conclusion}

A spreadsheet-aided engineering design tool has been constructed and utilized in the design of a parachute system. Although still in the early development stage it was found to be a valuable design tool, allowing for examination and evaluation of multiple design iterations.

The future development of this spreadsheetaided-engineering design tool will encompass the concept of "expert" systems to assist the designer in making design choices. In addition, plans are being formulated to create the input/output linkages to the FORTRAN analysis codes used to evaluate the force-time-trajectory history, deployment and inflation characteristics, and steady state structural loads.

Much work remains to convert this project from an experimental "design toy" into a valuable design application tool that can be universally used by the parachute design engineer.

\section{Disclaimer}

The spreadsheet program described in this paper and the examples shown have only been used to design and evaluate a few parachute systems. These designs were performed with the knowledge that the program was still a prototype. During the course of performing these designs, errors have been found and limitations have been noted. It should be understood that this program is being developed to aid a knowledgeable parachute engineer design a parachute system. There is much development and validation work to be done for this program to become useful to a new or inexperienced parachute engineer.

\section{References}

[1]Waye, D. E., "The Development of a Flight Termination Parachute System for a 1900-1b Payload," to be presented, AIAA 14th Aerodynamic Decelerator Technology Conference, San Francisco, CA, Paper No. AIAA97-1514, June 1997.

[2]Waye, D. E., "Parachute Design Case Studies", Lectures of the University of Minnesota Parachute Systems Technology Short Course, Houston, TX, June 1994.
[3]Knack, T. W., Parachute Recovery Systems Design Manual, Para Publishing, Santa Barbara, CA, 1992.

[4]Waye, D. E., "Computer Design Code for Conical Ribbon Parachutes," AIAA 9th

Aerodynamic Decelerator and Balloon Technology Conference, Albuquerque, NM, Paper No.

AIAA86-2487, October 1986.

[5]Sundberg, D. W., "A New Solution Method for Steady-State Canopy Structural Loads", Journal of Aircraft, Vol. 25, November 1988, pp. 1045-1051. 